\title{
Estimation Model of Mangrove Carbon Stock Using LDCM Imagery
}

\author{
Firman Farid Muhsoni ${ }^{\mathrm{a}}$ \\ ${ }^{a}$ Aquatic Resources Management, University of Trunojoyo Madura, Bangkalan, Indonesia
}

\begin{abstract}
A B S T R A C T
Mangroves are one of the forest ecosystems with the capacity to reduce greenhouse effect. However, there is limited data on the carbon absorbent properties, and, a fast as well as accurate method of estimating the stock in mangrove is needed. The objective of this research, therefore, was to obtain an estimation model of mangrove carbon stocks, using LDCM satellite imagery. This development involved a hybrid method, where information obtained from LDCM satellite imagery were combined with the field data. The result of this study identified the best model to estimate carbon stock. This involved the combination of total vegetation stock, using the VARI vegetation index (power regression/ geometry) and soil composition, based on six variables multiple regression. The\%RMSE test result was determined to be $9.58 \%$. In addition, field data was not required in models involving two variables (MSAVI vegetation index and average sediment depth $100.6 \mathrm{~cm}$ ), and the \% RMSE determined was $34.18 \%$.
\end{abstract}

Keywords: Mangrove carbon stock, Hybrid, LDCM Imagery.

Article History

Received 27 November 20

Received in revised form 27 November 20

Accepted 8 November 20

\section{Introduction}

Deforestation refers toactivities involved in reduced forest vegetation, which is responsible for $\mathrm{CO} 2$ absorption. In addition, forests in Indonesia have the potential to absorb about $48 \%$ gas emissions, hence adequate management is very important (Wibowo, 2010). These include the mangroves, as one of the ecosystems with a potential to reduce the greenhouse effect and cause climate change (Komiyama, et al., 2008). Moreover, there is limited information and data on the intrinsic carbon absorbent capacity (Klinkhamer, 1995). Several studies have recognized mangrove as an ecosystem with the highest competence in this aspect, compared to other forests forms (tropical, subtropical or boreal forests). This is attributed to the significant storage of carbon in the organic-rich soil (Hooijer et al., 2010; Page et al., 2011; Donato et al., 2012; Kauffman \& Donato, 2012).

Furthermore, only about $2 \%$ of the coastal areas worldwide are occupied by mangroves, andare responsible for $5 \%$ primary production, $12 \%$ respiration, and approximately $30 \%$ carbon absorption. During the incidence of mangrove deforestation, only roughly $0.7 \%$ of the tropical forest area is anticipated to supply $10 \% \mathrm{CO} 2$ (Alongi \& Mukhopadhyay, 2015). Moreover, about 50\% more mangroves in the world have been destroyed with approximately $35 \%$ resulted from cultivation and coastal development within the last two decades(Feller et al., 2010). Previous studies have shown the existence of 70 species, and about $16 \%$ are in danger of extinction (Polidoro et al., 2010). The extent of damage reported in Indonesia alone is up to $40 \%$ from 1986-1990 (Noor et al., 1999).
In addition, appropriate and accurate methods are required to obtain more valid carbon stock related information. The objective of this study, therefore, is to develop a mangrove carbon stock estimation model using LDCM imagery. Thisinvolved a hybrid combination of satellite image and field data.

\section{Materials And Methods}

The study location were Larangan, Galis, Pademawu, and Tlanakan subdistricts of Pamekasan Regency. Furthermore, the stages of this investigation were as follows: (1) LDCM imagery analysis using vegetation index, with about 14 models, including GNDVI (Green normalized difference Vegetation index) (Gitelson \& Merzlyak, 1997), GR (Green Ratio) (Waseret al., 2014), MSAVI (modified SAVI) (Qi et al. , 1994), NDVI (normalized difference vegetation index) (Rouse et al., 1973; Pettorelliet al., 2011; Gitelson \& Merzlyak, 1997), NDWI (Normalized Difference Water Index) (Gao, 1996), NNIP (Normalized Near Infrared) (Sripadaet al, 2005; Ng et al., 2017), RVI (Ratio Vegetation index) (Broge\& Leblanc, 2001), MTV (Modified Triangular Vegetation Index 1) (Haboudaneet al., 2004), MTV 2 (Modified Triangular Vegetation Index 2) (Haboudaneet al., 2004), RDVI (renormalized difference vegetation index) (Roujean \& Breon, 1995), VARI (vegetation atmospherically resistant index) (Gitelsonet al., 2002), VI green ( Gitelsonet al., 2002), MSR (Modified Simple Ratio) (Chen, 1996; Haboudan eet al., 2004), TVI (triangular vegetation index) (Broge\& Leblanc, 2001). (2) Mangrove data measurement for biomass and carbon estimations. (3) Hybrid modeling was

* Corresponding author: Firman Farid Muhsoni.Phone : 081931724270.

E-mail address: firmanfaridmuhsoni@ trunojoyo.ac.id 
then performed using a combination of satellite imagery and field measurement data, according to Gumbricht, (2015).

The test for accuracy involved using correlation coefficient (r) and Root Mean Square Error (RMSE) to determine the best vegetation index transformation to model carbon stocks in mangroves (Clark et al., 2011; Cartuset al., 2014; Kulawardhana. et al., 2014; Frananda et al., 2015; Hu et al., 2016). Subsequently, RMSE test was conducted using 30 plots, with the following equation:

$R M S E=\sqrt{\frac{i}{n} \sum_{i=1}^{n}\left(x_{i}-y_{i}\right)^{2}}$

RMSE $\%=100 \times \frac{R M S E}{\bar{Y}}$

where: $\boldsymbol{x}_{\boldsymbol{i}}=$ measured carbon stock, $\boldsymbol{y}_{\boldsymbol{i}}=$ carbon stock estimation, $\bar{Y}=$ average measured carbon stock(Weng, 2010a; Chuvieco et al., 2010;(Köhlet al., 2006)Vicharnakorn et al., 2014; Kamal, 2015; Alparone et al, 2015;Thenkabail, 2016; Alan et al., 2017;)

\section{Results and Discussion}

\subsection{Carbon content modeling of mangrove vegetation using LDCM imagery}

The field measurement results published in Muhsoniet al., (2020) showed a total mangrove carbon stock reaching $306.04 \mathrm{t} \mathrm{C} \mathrm{ha}^{-1}$. This comprises $82.88 \%$ for soil carbon, which is 4.8 times greater than others, including tree $(9.49 \%)$, root $(7.11 \%)$, and subsurface plant $(0.52 \%)$.

In addition, the carbon regression results estimated with LDCM imagery vegetation index showed the tendency for RMSE determination values to reach $>0.5$ using the following combinations with regression: VARI Power/geometry, VARI exponential, VI green Power/geometry, VI green exponential, GR Power/geometry, VARI Polynomial, GR Exponential. The research by Muhsoniet al., (2018) identified the following combinations to be most appropriate, while using Sentinel 2 imagery: exponential regression for vegetation index NDVI, NDVI2, NNIP, SVI, MTV2, RDVI, MSR and power/geometry for GNDVI vegetation index, NDVI, NDVI2, NNIP, SVI, RDVI, MSR.

Table 1. RMSE test results and estimation model of the biomass carbon using LDCM imagery

\begin{tabular}{cllcc}
\hline No & $\begin{array}{c}\text { Vegetation } \\
\text { Index } \\
\text { Regression (X) }\end{array}$ & $\begin{array}{c}\text { Equation Model of } \\
\text { Biomass Carbon * }\end{array}$ & $\begin{array}{c}\text { RMSE } \\
\text { (ton } \\
\text { piksel }^{-1} \text { ) }\end{array}$ & $\mathbf{R}^{\mathbf{2}}$ \\
\hline 1 & $\begin{array}{l}\text { VARI } \\
\text { Power/geometry }\end{array}$ & $\mathrm{y}=66,38 \mathrm{x}^{2,104}$ & 1,39791 & 0,624 \\
2 & $\begin{array}{l}\text { Exponential } \\
\text { VARI }\end{array}$ & $\mathrm{y}=0,298 \mathrm{e}^{9,651 \mathrm{x}}$ & 1,44074 & 0,66 \\
3 & $\begin{array}{l}\text { VI green } \\
\text { Power/geometry }\end{array}$ & $\mathrm{y}=136,4 \mathrm{x}^{1,997}$ & 1,52565 & 0,545 \\
4 & $\begin{array}{l}\text { VI green } \\
\text { exponential }\end{array}$ & $\mathrm{y}=0,354 \mathrm{e}^{13,88 \mathrm{x}}$ & 1,5849 & 0,563 \\
5 & $\begin{array}{l}\text { GR Power } / \\
\text { geometry }\end{array}$ & $\mathrm{y}=0,368 \mathrm{x}^{6,759}$ & 1,59207 & 0,563 \\
6 & $\begin{array}{l}\text { Polynomial } \\
\text { VARI }\end{array}$ & $\begin{array}{l}\mathrm{y}=117,4 \mathrm{x}^{2}-21,41 \mathrm{x} \\
+1,646\end{array}$ & 1,62664 & 0,58 \\
\hline
\end{tabular}

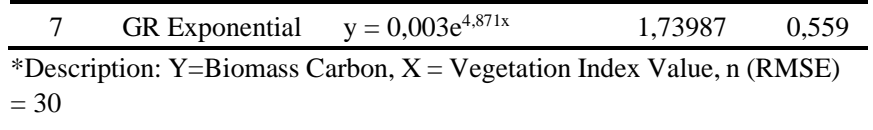

The best RMSE test results for mangrove vegetation carbon were obtained by using a VARI (vegetation atmospherically resistant index) with power/geometry regression for LDCM imagery (1.39791 ton / 900m-2). This result was different from the Sentinel-2 imagery (published in Muhsoniet al., 2018) at 0.247056 ton $100 \mathrm{~m}^{-2}$, although the best vegetation index corresponded to NNIP. Kamal (2015) performed a study in Karimunjawa using Landsat TM imagery, and showed SR as the best index, with RMSE of 1.23 ton $900 \mathrm{~m}^{-2}$. Meanwhile, SPOT 5 and Landsat TM were used by Hamdanet al. (2013) and NDVI was obtained as superior, alongside the adoption of non-linear regression.

\subsection{Estimation Model of Soil Carbon Content using LDCM imagery.}

The soil carbon was estimated using multiple regression modeling of LDCM imagery based on the following simulations: (referring to research by Muhsoniet al., 2018)

1. Two variable regression, including $\mathrm{X} 1=$ the index value of the LDCM imagery vegetation and $\mathrm{X} 2=$ the depth of the sediment.

2. Regression with three variables, specifically $X 1=$ vegetation index value of LDCM image, X2 = sediment depth and X3 = bulk Density,

3. Regression with 6 variables, including $X 1=$ vegetation index value of LDCM imagery, X2 = sediment depth, X3 = Bulk Density, X4 $=\% \mathrm{C}$ depth $0-15 \mathrm{~cm}, \mathrm{X} 5=\% \mathrm{C}$ depth $15-50 \mathrm{~cm}$ and $\mathrm{X} 6=\% \mathrm{C}$ depth $>$ $50 \mathrm{~cm}$.

Subsequently RMSE test results were analyzed on the regression, alongside the most significant value determined for six, three and two variables. The outcome of multiple modeling for the best six variables using LDCM images was RDVI (renormalized difference vegetation index), with an RMSE of 3.14479 ton $900 \mathrm{~m}^{-2}$, while MSAVI (modified Soil-Adjusted Vegetation Index) provided the best variable at 6.15302 ton $900 \mathrm{~m}^{-2}$. In addition, the best two-variable model was MSAVI at 9.47993 ton $900 \mathrm{~m}^{-2}$. Muhsoni et al., (2018) used Sentinel-2 imagery, and NDRE (Normalized difference Red-Edge index) with RMSE of 0.5011 ton $100 \mathrm{~m}^{-2}$ as well as WVVI (World View Improved Vegetative Index) at 0.5011 ton $100 \mathrm{~m}^{-2}$ were selected. Based on the three variables evaluation, VIRE (Vegetation Index based on RedEdge) at 0.5924 ton $100 \mathrm{~m}^{-2}$ was determined to be superior, while NDRE at 0.7747 ton $100 \mathrm{~m}^{-2}$ was chosen for the two variable model.

3.3. Determination of the Best Model Mangrove Carbon Content using LDCM imagery

LDCM imagery modeling was performed by combining the carbon mangrove vegetation and soil carbon estimation models. Based on several simulations, the overall best was determined as follows (pixel area 30x30 m):

1. Model 1 with the following equation (Figure 1):

$\mathrm{Y}=(66,38 *(\mathrm{X} 1 \wedge 2,104))+(-97,618+2,740589 * \mathrm{X} 2 \quad+0,36241 * \mathrm{X} 3+$

$40,69228 * X 4-7325,77 * X 5+9758,635 * X 6-526,508 * X 7)$

Description: 
$\mathrm{X} 1=$ VARI vegetation index,

$\mathrm{X} 2=\mathrm{RDVI}$ vegetation index,

VARI $=\frac{(G-R)}{(G+R-B)}$,

$\mathrm{RDVI}=\left[(N I R-R) /(N I R+R)^{2}\right]$

$\mathrm{G}=$ band $3, \mathrm{R}=$ band $4, \mathrm{~B}=$ band $2, \mathrm{NIR}=$ band 5 ,

$\mathrm{X} 3=$ Sediment depth $(\mathrm{cm})$,

$\mathrm{X} 4=$ Bulk density $\left(\mathrm{g} \mathrm{cm}^{-3}\right)$,

$\mathrm{X} 5=\% \mathrm{C}$ depth $0-15 \mathrm{~cm}$,

$\mathrm{X} 6=\% \mathrm{C}$ depth $15-50 \mathrm{~cm}$,

$\mathrm{X} 7=\% \mathrm{C}$ depth $>15 \mathrm{~cm}$

2. Model 2 with the following equation (Figure 2):

$\mathrm{Y}=(66,38 *(\mathrm{X} 1 \wedge 2,104))+(-46,1009+69,02285 * \mathrm{X} 2+0,182429 * \mathrm{X} 3+$

$19,40405 * \mathrm{X} 4)$

Description:

$\mathrm{X} 1=\mathrm{VARI}$ vegetation index,

$\mathrm{X} 2=$ MSAVI vegetation index,

VARI $=\frac{(G-R)}{(G+R-B)}$,

MSAVI $=\frac{1}{2}\left[2 * N I R 1+1-\sqrt{(2 * N I R 1+1)^{2}-8 *(N I R 1-R)}\right]$,

$\mathrm{G}=$ band $3, \mathrm{R}=$ band $4, \mathrm{~B}=$ band $2, \mathrm{NIR}=$ band 5 ,

$\mathrm{X} 3=$ Sediment depth $(\mathrm{cm})$,

$\mathrm{X} 4=$ Bulk density $\left(\mathrm{g} \mathrm{cm}^{-3}\right)$.

3. Model 3 with the following equation (Figure 3):

$\mathrm{Y}=\left(66,38^{*}\left(\mathrm{X} 1^{\wedge} 2,104\right)\right)+(-13,91+20,54032 * \mathrm{X} 2+0,26787 * \mathrm{X} 3)$

Description:

$\mathrm{X} 1=\mathrm{VARI}$ vegetation index,

$\mathrm{X} 2=$ MSAVI vegetation index,

VARI $=\frac{(G-R)}{(G+R-B)}$,

MSAVI $=\frac{1}{2}\left[2 * N I R 1+1-\sqrt{(2 * N I R 1+1)^{2}-8 *(N I R 1-R)}\right]$,

$\mathrm{G}=$ band $3, \mathrm{R}=$ band $4, \mathrm{~B}=$ band $2, \mathrm{NIR}=$ band 5 ,

$\mathrm{X} 3=$ Sediment depth $(\mathrm{cm})$.

4. Model 4 with the following equation (Figure 4):

$\mathrm{Y}=(66,38 *(\mathrm{X} 1 \wedge 2,104))+(-13,91+20,54032 * \mathrm{X} 2+0,26787 * \mathrm{X} 3)$

Description:

$\mathrm{X} 1=\mathrm{VARI}$ vegetation index,

$\mathrm{X} 2$ = MSAVI vegetation index,

VARI $=\frac{(\boldsymbol{G}-\boldsymbol{R})}{(\boldsymbol{G}+\boldsymbol{R}-\boldsymbol{B})}$,

MSAVI $=\frac{1}{2}\left[2 * N I R 1+1-\sqrt{(2 * N I R 1+1)^{2}-8 *(N I R 1-R)}\right]$,

$\mathrm{G}=$ band $3, \mathrm{R}=$ band $4, \mathrm{~B}=$ band $2, \mathrm{NIR}=$ band 5 ,

$\mathrm{X} 3$ = average sediment depth $(100,63 \mathrm{~cm})$,

The results showed model 1 as the best modeling to estimate mangrove carbon with LDCM imagery. This involves a combination of data obtained using the vegetation atmospherically resistant index (VARI) power/geometry regression equation and soil content determinations with 6 variables multiple regression. Therefore, the RMSE model test outcome was 2.53079 tonnes $900 \mathrm{~m}-2$ and $9.58 \%$. However, model 2 merges the information acquired from VARI with soil carbon estimations, using threevariable multiple regression, and generated an RMSE of 6.87089 ton $900 \mathrm{~m}-$ $2(26.0 \%)$. Meanwhile, the combination in Model 3 uses two variables, with RMSE of 6.65033 ton $900 \mathrm{~m}-2$ (25.17\%). In addition, model 4 entered the average sediment depth value obtained in the field measurement results of $100.63 \mathrm{~cm}$. The most suitable equation comprises the incorporation of vegetation biomass carbon estimates using the power regression equation/geometry of VARI with three-variable multiple regression for soil. This generated an RMSE of 9.03122 ton $900 \mathrm{~m}-2$ (34.180\%).
Compared to the mangrove carbon stock modeling with Sentinel 2 imagery, Model 1 involved the NNIP index during vegetation carbon estimation with power/geometry regression, alongside the application of six variables multiple regression with NDRE or WVVI index to determine the soil stock. This generated a \%RMSE result of $16.12 \%$. In addition, model 2 used the NNIP index to estimate the vegetation carbon with threevariable applied with VIRRE to determine the soil stock. The \% RMSE was evaluated to be $19.03 \%$. In addition, NNIP was also applied in model 3 , although two variables were used together with the NDRE index for soil estimations, which collectively obtained a \% RMSE of $24.63 \%$. Moreover, similar technique was implemented in Model 4, and 3-variable multiple regression was adopted, where the \%RMSE test results was determined as 33.89\% (Muhsoniet al., 2018).

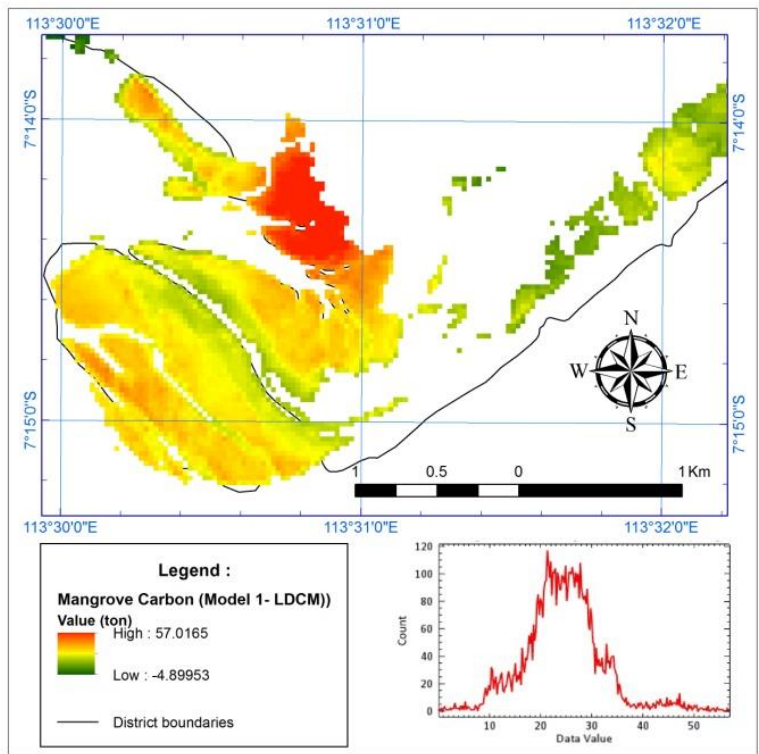

Figure 1. Map of mangrove carbon stock from Model 1 LDCM imagery. 


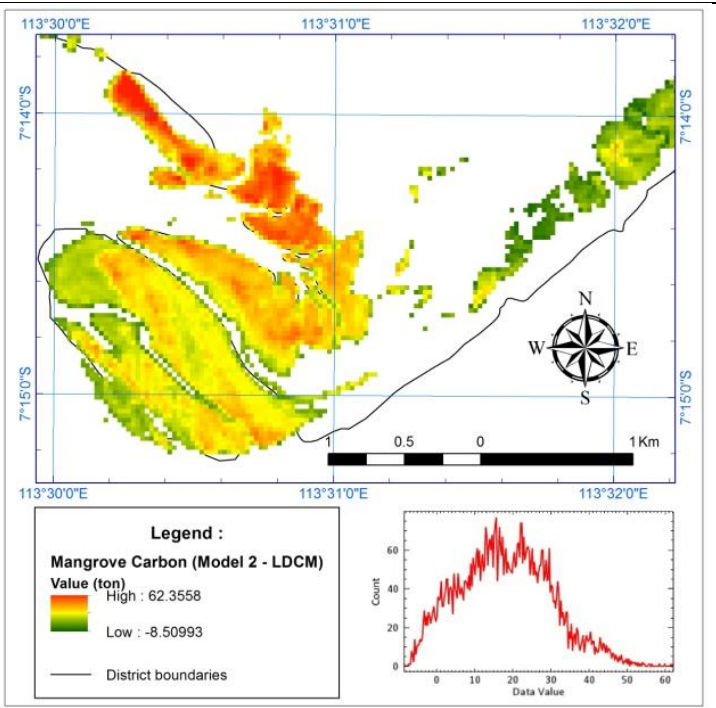

Figure 2. Map of mangrove carbon stock from Model 2 LDCM imagery

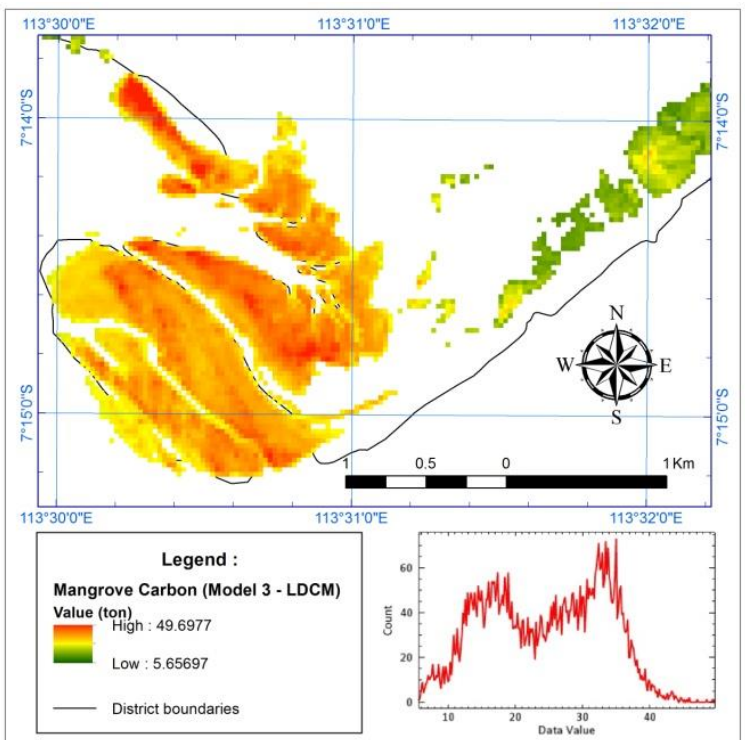

Figure 3. Map of mangrove carbon stock from Model 3 LDCM imagery.

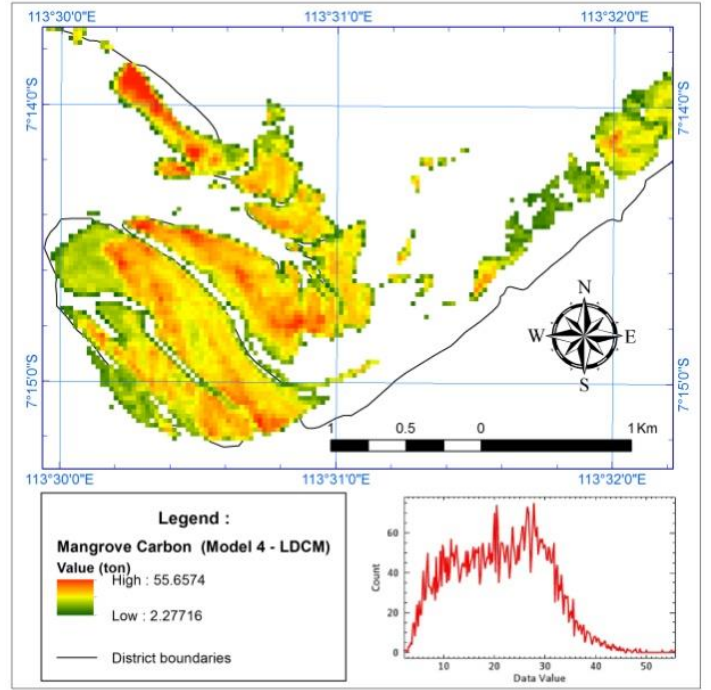

Figure 4. Map of mangrove carbon stock from Model 4 LDCM imagery.

Figure 4. Map of mangrove carbon stock from Model 4 LDCM imagery.

\section{Conclusion}

The model with the best LDCM imagery was used to estimate the mangrove vegetation carbon stock. This comprised a combination of the VARI vegetation index (red, green and blue), and soil sediment estimations derived using RDVI and MSAVI (encompassing red channels and Near Infra Red). The \%RMSE test result was $9.58 \%$. However, field data is not required in models involving similar combinations, where two variable multiple regression (MSAVI vegetation index and average sediment depth $100.6 \mathrm{~cm}$ ) are applied in determining the soil stock. The \%RMSE test result was determined as $34.18 \%$

\section{Acknowledgements}

The author would like to thank the Trunojoyo University Institute for Research and Community Service.

\section{REFERENCES}

[1] Alan, J., Castillo, A., Apan, A. A., Narayan, T., \& Iii, S. G. S. (2017). Geoderma Soil C quantities of mangrove forests, their competing land uses , and their spatial distribution in the coast of Honda Bay , Philippines. Geoderma, 293, 82-90. https://doi.org/10.1016/j.geoderma.2017.01.025

Alongi, D., \& Mukhopadhyay, S. (2015). Contribution of mangroves to coastal carbon cycling in low latitude seas. Agricultural and Forest 
Meteorology,

213 ,

$266-272$.

https://doi.org/10.1016/j.agrformet.2014.10.005

Alparone, L., Aiazzi, B., Baronti, S., \& Garzelli, A. (2015). Remote Sensing Image Fusion.

Broge, N. H., \& Leblanc, E. (2001). Comparing prediction power and stability of broadband and hyperspectral vegetation indices for estimation of green leaf area index and canopy chlorophyll density. Remote Sensing of Environment, 76(2), 156-172. https://doi.org/10.1016/S0034-4257(00)00197-8

Cartus, O., Kellndorfer, J., Walker, W., Franco, C., Bishop, J., Santos, L., \& Fuentes, J. (2014). A national, detailed map of forest aboveground carbon stocks in Mexico. Remote Sensing, 6(6), 55595588. https://doi.org/10.3390/rs6065559

Chen, J. M. (1996). Evaluation of vegetation indices and a modified simple ratio for boreal applications. Canadian Journal of Remote Sensing, 22(3), 229-242. https://doi.org/10.1080/07038992.1996.10855178

Chuvieco, E., Li, J., \& Yang, X. (2010). Advances in Earth Observation of Global Change. Springer. https://doi.org/DOI 10.1007/978-90-4819085-0

Clark, M. L., Roberts, D. A., Ewel, J. J., \& Clark, D. B. (2011). Estimation of tropical rain forest aboveground biomass with small-footprint lidar and hyperspectral sensors. Remote Sensing of Environment, 115(11), 2931-2942. https://doi.org/10.1016/j.rse.2010.08.029

Feller, I. C., Lovelock, C. E., Berger, U., McKee, K. L., Joye, S. B., \& Ball, M. C. (2010). Biocomplexity in mangrove ecosystems. Annual Review of Marine Science, 2, 395-417. https://doi.org/10.1146/annurev.marine.010908.163809

Frananda, H., Hartono, \& Jatmiko, R. H. (2015). Komparasi Indeks Vegetasi untuk Estimasi Stok Karbon Hutan Mangrove Kawasan Segoro Anak pada Kawasan Taman Nasional Alas Purwo Banyuwangi , Jawa Timur. Majalah Ilmiah Globë, 17(2), 113-123.

Gao, B. C. (1996). NDWI - A normalized difference water index for remote sensing of vegetation liquid water from space. Remote Sensing of Environment, 58(3), 257-266. https://doi.org/10.1016/S00344257(96)00067-3

Gitelson, A. A., \& Merzlyak, M. N. (1997). Remote estimation of chlorophyll content in higher plant leaves. International Journal of Remote Sensing, 18(12), 37-41. https://doi.org/10.1080/014311697217558

Gitelson, A., Kaufman, Y., Stark, R., \& Rundquist, D. (2002). Novel algorithms for remote estimation of vegetation fraction. Remote Sensing of Environment, 80(1), 76-87. https://doi.org/10.1016/S0034-4257(01)00289-9

Gumbricht, T. (2015). Hybrid Mapping of Pantropical Wetlands from Optical Satellite Images, Hydrology, and Geomorphology. In R. W. Tiner, M. W. Lang, \& V. V. Klemas (Eds.), Remote sensing of wetlands (pp. 435-454). CRC Press is an imprint of Taylor \& Francis Group, an Informa business. http://www.taylorandfrancis.com

Haboudane, D., Miller, J. R., Pattey, E., Zarco-Tejada, P. J., \& Strachan, I. B. (2004). Hyperspectral vegetation indices and novel algorithms for predicting green LAI of crop canopies: Modeling and validation in the context of precision agriculture. Remote Sensing of Environment, 90(3), https://doi.org/10.1016/j.rse.2003.12.013

Hamdan, O., Khairunnisa, M., Ammar, A., Mohd Hasmadi, I., \& Khali Aziz, H. (2013). Mangrove Carbon Stock Assessment By Optical Satellite Imagery. Journal of Tropical Forest Science, 25(4), 554565.

Hooijer, A., Page, S., Canadell, J. G., Silvius, M., Kwadijk, J., Wösten, H., \& Jauhiainen, J. (2010). Current and future CO2 emissions from drained peatlands in Southeast Asia. Biogeosciences, 7(5), 15051514. https://doi.org/10.5194/bg-7-1505-2010

Hu, T., Su, Y., Xue, B., Liu, J., Zhao, X., Fang, J., \& Guo, Q. (2016). Mapping Global Forest Aboveground Biomass with Spaceborne LiDAR, Optical Imagery, and Forest Inventory Data. Remote Sensing, 8(7), 565. https://doi.org/10.3390/rs8070565

Kamal, M. (2015). Remote Sensing for Multi-scale Mangrove Mapping. In
School of Geography. https://doi.org/10.14264/uql.2015.847

Kauffman, J., \& Donato, D. (2012). Protocols for the measurement, monitoring and reporting of structure, biomass and carbon stocks in mangrove forests. In Center for International Forestry: Vol. Working pa. https://doi.org/10.17528/cifor/003749

Klinkhamer, P. G. L. (1995). Plant allometry: The scaling of form and process. Trends in Ecology \& Evolution, 10(3), 134 https://doi.org/10.1016/S0169-5347(00)89015-1

Köhl, M., Magnussen, S., \& Marchetti, M. (2006). Sampling Methods, Remote Sensing and GIS Multiresource Forest Inventory. In Springer-Verlag Berlin Heidelberg New York (Vol. 3, Issues 2-3). https://doi.org/10.1300/J091v03n02_06

Komiyama, A., Ong, J. E., \& Poungparn, S. (2008). Allometry, biomass, and productivity of mangrove forests: A review. Aquatic Botany, 89(2), 128-137. https://doi.org/10.1016/j.aquabot.2007.12.006

Kulawardhana, R. W., Popescu, S. C., \& Feagin, R. A. (2014). Fusion of lidar and multispectral data to quantify salt marsh carbon stocks. Remote Sensing of Environment, 154, 345-357. https://doi.org/10.1016/j.rse.2013.10.036

Muhsoni, F. F., Sambah, A. B., Mahmudi, M., \& Wiadnya, D. G. P. (2018). Estimation of mangrove carbon stock with hybrid method using image Sentinel-2. International Journal of GEOMATE, 15(49). https://doi.org/10.21660/2018.49.52661

Muhsoni, F. F., Sambah, A. B., Mahmudi, M., \& Wiadnya, D. G. R. (2020). Comparative study of carbon stock in estuarine and oceanic mangroves. Malayan Nature Journal, 72(9), 189-199. https://www.mnj.my/

Ng, W.-T., Rima, P., Einzmann, K., Immitzer, M., Atzberger, C., \& Eckert, S. (2017). Assessing the Potential of Sentinel-2 and Pléiades Data for the Detection of Prosopis and Vachellia spp. in Kenya. Remote Sensing, 9(1), 74. https://doi.org/10.3390/rs9010074

Noor, Y. R., Khazali, M., \& Suryadiputra, I. N. N. (1999). Panduan Pengenalan Mangrove di Indonesia. Wetlands International Indonesia Programme.

Page, S. E., Rieley, J. O., \& Banks, C. J. (2011). Global and regional importance of the tropical peatland carbon pool. Global Change Biology, 17(2), 798-818. https://doi.org/10.1111/j.13652486.2010.02279.x

Pettorelli, N., Ryan, S., Mueller, T., Bunnefeld, N., Jedrzejewska, B., Lima, M., \& Kausrud, K. (2011). The Normalized Difference Vegetation Index (NDVI): Unforeseen successes in animal ecology. Climate Research, 46(1), 15-27. https://doi.org/10.3354/cr00936

Polidoro, B. A., Carpenter, K. E., Collins, L., Duke, N. C., Ellison, A. M., Ellison, J. C., Farnsworth, E. J., Fernando, E. S., Kathiresan, K., Koedam, N. E., Livingstone, S. R., Miyagi, T., Moore, G. E., Nam, V. N., Ong, J. E., Primavera, J. H., Salmo, S. G., Sanciangco, J. C., Sukardjo, S., ... Yong, J. W. H. (2010). The loss of species: Mangrove extinction risk and geographic areas of global concern. Plos One, 5(4), 1-10. https://doi.org/10.1371/journal.pone.0010095

Qi, J., Chehbouni, A., Huete, A. R., Kerr, Y. H., \& Sorooshian, S. (1994). A modified soil adjusted vegetation index. Remote Sensing of Environment, 48(2), 119-126. https://doi.org/10.1016/00344257(94)90134-1

Roujean, J. L., \& Breon, F. M. (1995). Estimating PAR absorbed by vegetation from bidirectional reflectance measurements. Remote Sensing of Environment, 51(3), 375-384. https://doi.org/10.1016/0034-4257(94)00114-3

Rouse, J. W., Haas, R. H., Schell, J. A., \& Deering, D. W. (1973). Monitoring the vernal advancement and retrogradation (green wave effect) of natural vegetation. Progress Report RSC 1978-1, 112. https://doi.org/19740008955

Sripada, R. P., Heiniger, R. W., White, J. G., \& Weisz, R. (2005). Aerial Color Infrared Photography for Determining Late-Season Nitrogen Requirements in Corn. Agronomy Journal, 97, 1443-1451. https://doi.org/10.2134/agronj2004.0314

Thenkabail, P. S. (2016). Remotely Sensed Data Characterization, Classification, and Accuracies. Taylor \&Francis Group, LLC. http://www.taylorandfrancis.com 
Vicharnakorn, P., Shrestha, R. P., Nagai, M., Salam, A. P., \& Kiratiprayoon, S. (2014). Carbon stock assessment using remote sensing and forest inventory data in Savannakhet, Lao PDR. Remote Sensing, 6(6), 5452-5479. https://doi.org/10.3390/rs6065452

Waser, L. T., Küchler, M., Jütte, K., \& Stampfer, T. (2014). Evaluating the potential of worldview-2 data to classify tree species and different levels of ash mortality. Remote Sensing, 6(5), 4515-4545. https://doi.org/10.3390/rs6054515
Weng, Q. (2010). Remote Sensing and GIS Integration Theories, Methods, and Applications.

$\mathrm{Mc}$

Graw

Hill. https://doi.org/10.1191/0309133304pp413pr

Wibowo, A. (2010). Measurable, Reportable dan Verifyable (MRV) Untuk Emisi Gas Rumah Kaca dari Kegiatan Kehutanan. In N. Masripatin \& C. Wulandari (Eds.), REDD and Forest Governance (pp. 3-22). Pusat Penelitian Sosial Ekonomi dan Kebijakan Kehutanan. 